\title{
Applying the Omaha System to Determine Health Problems Among Child Workers: Example from a Suburb of Istanbul
}

Ozlem Koseoglu Omek ( $\sim$ ozlem.koseoglu@med.uni-muenchen.de )

University Hospital, LMU Munich

Nurcan Kolac

Marmara University

Saadet ozdemir

Istanbul Bilgi University

\section{Research Article}

Keywords: The Omaha system, child labor, mental health, neglect, income, secondary school children

Posted Date: February 28th, 2022

DOI: https://doi.org/10.21203/rs.3.rs-1346207/v1

License: (c) (1) This work is licensed under a Creative Commons Attribution 4.0 International License. Read Full License 


\section{Abstract}

Background: Education has important effects on the physical and psychosocial development of children. However, a high rate of children worldwide engaged in child labour, and a majority of them deprived of formal education opportunities due to work. Work conditions have a multifaceted, negative effect on children's health and quality of life. In this context, it was aimed to determine the physiological, psychosocial, and health-related behaviours, as well as the environmental problems of migrant and non-migrant child workers in lower-secondary schools in using the Omaha System Problem Classification Scheme, and to examine related factors.

Method: This is descriptive-correlational and observational study. The sample was selected using a purposive sampling method. The study population comprised migrant and non-migrant child workers from two lower-secondary schools in suburb of Istanbul. Descriptive Characteristics Assessment Form and Nightingale Notes Software based on the terminology of the Omaha System were used for data collection.

Results: The participants were 81 child workers aged $10-13$ years, $86 \%$ of them were male. $12 \%$ of them were migrant from Syria. $85 \%$ worked to contribute their family income. The most common health problems were mental health, neglect, income, oral health, nutrition, personal care, physical activity, sleep and rest patterns, and neighbourhood/workplace safety. There was an association between mental health problems and family health status; between individual health status and oral health as well as role change; between maternal education level and oral health as well as personal care and between nutrition and paternal education level $(p<.05)$.

Conclusion: The Omaha system was found suitable for determining health problems of migrant and non-migrant juvenile labour. However, it is necessary to prevent poverty, develop the understanding of the social state, and comply with legal norms. We recommend that researchers examine the health of child workers in long-term and mixed-method observational studies.

\section{Introduction}

Education has important effects on the physical and psychosocial development of children. A healthy society requires that all children have access to healthy, efficient education. However, 1 in 10 children (in total, 63 million girls and 97 million boys) worldwide engage in child labour, and over one-third of child workers aged 5 to 17 years do not attend school $(1,2)$. The highest prevalence of child labour is in sub-Saharan Africa, while the lowest is in Europe and North America. Among European countries, Turkey has the highest prevalence of child labour $(1,3)$. The reasons that children work differ. However, poverty, migration, and lack of schooling opportunities are reported as the most common reasons for non-schooling $(1,2,4)$. Recent studies have shown that economic contribution to family is a common reason that children work $(3,5)$. In of Turkey, both immigrant and non-immigrant children with low socioeconomic status are victims of socio-political problems resulting from unplanned migration due to the war in Syria. According to the latest (2019-2020) TUIK data, Turkey had over 5 million students in secondary school (6) but also over 700 thousand child and adolescent workers in 2019 . Overall, $80 \%$ of these workers were $15-17$ years of age, $16 \%$ were $12-14$ years of age, and $4 \%$ were $5-11$ years of group. Among them, $71 \%$ were boys, and $68 \%$ were both working and continuing formal education. Almost $31 \%$ of child workers laboured in agriculture, $24 \%$ in industry, and $45.5 \%$ in the service sector (3). There may be more child workers than is reported, as it is forbidden to employ children under the age of 14 according to regulations in Turkey. Beyond that, the COVID-19 pandemic may have a high impact in increase of the child workers' prevalence, especially in low-middle income countries such as Turkey, due to its large impact on economies, working conditions, and education systems (7).

Child labour gravely impacts physical health (8-10), mental health (10-14), childhood maltreatment such as abuse and neglect (15,16), and nutritional status (9). According to recent studies, levels of depression and anxiety among children are already high, and they are increasing $(11,12,17)$. Suicide ideation and attempts are also on the rise (18). However, child labourers are under higher risk of health problems due to unequal life and working conditions(19). Children who have to work may also have difficulties in acquiring and maintaining healthy lifestyle behaviours such as healthy eating and exercise (9). In addition, they are more likely to be exposed to labour violations, fatal and non-fatal work accidents, and injury at the workplace compared to adults or peer groups attending school full-time $(9,20)$. For example, nearly 2,500 workers lost their lives in 2020 due to work accidents in Turkey, among whom $3 \%$ were younger than 17 years of age (22 workers were younger than 14, and 46 were 15-17 years in age). In the same year, 101 migrant workers lost their lives in a work accident (21). Recent studies have also shown a significant association between the prevalence of occupational accidents and injuries and child labour (9,22), but migrant child workers experience accidents and injuries more frequently (20). It is known that these children, who are exposed to conditions and responsibilities that are not suitable for their biopsychosocial developmental period, experience malnutrition, low levels of academic success, and greater difficulty in establishing a healthy future $(13,14,23)$.

Every child should have healthy living conditions and free, accessible educational opportunities, which are their most basic rights from birth. However, some children, especially those with low socioeconomic status (whether displaced immigrants or non-immigrants), seem to be deprived of these basic rights $(20,24,25)$. On the other hand, migrant child workers are much more vulnerable relative to non-migrant child workers due to linguistic and other barriers, such as lack of residency and lack of knowledge regarding occupation, education, and health systems (20). Work has a multifaceted, negative effect on children's health and quality of life $(13,14,23)$. However, according to a literature review conducted in the relevant field, studies examining the multifaceted health status of migrant and non-migrant child workers with a valid, reliable measurement tool, especially in Turkey, are limited. The current study was carried out because it is essential to identify the problems of children working in countries such as Turkey, which has recently experienced rapid socio-political and economic changes and has an increasing immigrant population, and to develop preventive programmes and initiatives. As mentioned, Turkey has the highest prevalence of child workers among European countries $(1,26)$. In this context, the Omaha System was used to determine the physiological and psychosocial health behaviours and environmental problems of working children in order to follow up and find solutions. This system is comprehensive and evidence based, and it is currently used by nurses, physicians, and other health staff internationally in schools, clinics, and community and occupational health centres. It is a standardised taxonomy providing a systematic approach to identifying the health problems and sociodemographic characteristics of individuals, families, 
and communities for the planning of reliable interventions. The Omaha System consists of the Problem Classification Scheme, Intervention Scheme, and Problem Rating $(27,28)$ (Fig. 1).

The aim of this descriptive-correlational and observational study was to determine the physiological, psychosocial, and health-related behaviours, as well as the environmental problems of migrant and non-migrant child workers in lower-secondary schools in a suburb of Istanbul, Turkey, using the Omaha System Problem Classification Scheme.

The following research questions were addressed in this study:

\section{Research question 1}

What are the health problems of migrant and non-migrant child workers in lower-secondary schools residing in a suburb of Istanbul, Turkey?

\section{Research question 2}

Is there an association between sociodemographic characteristics and health problems?

\section{Research question 3}

Is the Problem Classification Scheme of the Omaha System suitable for defining the health problems of migrant and non-migrant lower-secondary school children?

\section{Method}

\section{Sample and Settings}

This is descriptive-correlational and observational study. The study population comprised migrant and non-migrant child workers from two lower-secondary schools. The sample was selected using a purposive sampling method. The sample was determined during interviews conducted during the screening process for mental health and healthy lifestyle behaviours during the "School Health" project. Children who volunteered and spoke fluent Turkish, Kurdish, or Arabic were included in the study.

The schools had 1200 enrolled children living in a suburb on the European side of Istanbul. Istanbul is the largest city in Turkey with over 15 million residents. It is also an attractive city for internal and international migrants due to job opportunities. The vast majority of people who live in the Istanbul region where the schools are located consist of internal migrants, and it is also an attractive region for international migrants, such as people from Syria. The majority of the residents have a low socioeconomic level.

We informed all students who also work, their families, school administrators, and teachers regarding the aims and procedures of the study. All participated in the study. Public health nurses collected data and followed the child workers between September 2019 and May 2020. The follow-up process was terminated at end of May 2020 due to obstacles during the Covid-19 pandemic.

\section{Measurement}

\section{Descriptive Characteristics Assessment Form}

The researcher modified the Descriptive Characteristics Assessment Form according to similar academic studies, research, and literature. It consisted of the following characteristics: sociodemographic, family, health, and work. An initial version of the form was piloted using 10 children in one school.

Nightingale Notes Software, developed by Champ Software (Mankato, MN), is an electronic reporting system based on the terminology of the Omaha System. It is international and used in a variety of health-related disciplines $(27,29)$. The software consists of two parts. The first records demographic and health information. The second part comprises three components of the Omaha System. Of them, the Problem Classification Scheme and the Intervention Scheme were used in the present study. The Problem Rating Scale could not be used due to the limited time allowed by the school curriculum. The Problem Classification Scheme consists of four domains (environmental, psychological, physiological, health-related behaviours), with 42 defined health- and environment-related problems and 335 signs and symptoms. The Intervention Scheme consists of four categories (teaching, guidance, and counselling; treatments and procedures; case management; surveillance), with 76 targets (Fig. 1). The validity and reliability of the Turkish Omaha System were verified in 2006 (30). Data reports from Nightingale Notes Software can be downloaded in Excel, PDF, or graphic formats.

FIGURE 1

\section{Data Collection}

The data collection process was started after the students were invited to the school infirmary, and necessary explanations were made while the students were at school. Each data collection process was approximately 25 minutes in duration. The data were collected between September 2019 and May 2020 by public health nurses.

\section{Data Analysis}

The data entered into the Nightingale Notes Software system were reported in Excel (Microsoft, Redmond, WA) format and imported into SPSS 25.0 (IBM Corporation, Armonk, NY). Descriptive statistics were used to summarise the demographic data and outcome variables; chi-square test and independent $t$ test 
were used for comparative analysis. "Matrix visualisation" graphic was used in visualisation of the data (31).

\section{Results}

\section{Sociodemographic Characteristics}

The participants were 81 child workers aged 10-13 years. Most (86\%) were male and were non-migrant (88\%). Overall, 57\% expressed their (family) economic status as "good", and nearly 50\% (39 children) had a health problem (disease); 46 of the participants spoke Kurdish, and 15\% (12) spoke Arabic as second language. The majority ( $81 \%)$ had a relative or acquaintance at the workplace; $85 \%$ worked to support their family income, and $25 \%(20)$ had had an accident at work. In all, $41 \%$ (33) reported having a mother who was illiterate, and $21 \%$ (17) a father who was illiterate; only $10 \%$ (8) reported that their father had a high school diploma. Their ages at work commencement were between 7 and 13 years (mean: $9.8 \pm 1.3$ years), and their working hours per week were between 8 and 64 (Table 1). 


\begin{tabular}{|c|c|c|}
\hline Characteristics & $\mathbf{n}$ & $\%$ \\
\hline \multicolumn{3}{|l|}{ Age(year) } \\
\hline 10 & 19 & 23.5 \\
\hline 11 & 29 & 36 \\
\hline 12 & 17 & 21 \\
\hline 13 & 16 & 20 \\
\hline \multicolumn{3}{|l|}{ Gender } \\
\hline Male & 70 & 86 \\
\hline Female & 11 & 14 \\
\hline \multicolumn{3}{|l|}{ Nationality } \\
\hline Turkey & 67 & 88 \\
\hline Syria & 14 & 12 \\
\hline \multicolumn{3}{|l|}{ School degree } \\
\hline 5 th class & 21 & 26 \\
\hline 6th class & 30 & 37 \\
\hline 7th class & 22 & 27 \\
\hline 8th class & 8 & 10 \\
\hline \multicolumn{3}{|c|}{ Health problems of children (diseases) } \\
\hline Yes & 39 & 48 \\
\hline No & 42 & 52 \\
\hline \multicolumn{3}{|l|}{ Work accident } \\
\hline Yes & 20 & 25 \\
\hline No & 61 & 75 \\
\hline \multicolumn{3}{|l|}{ Education Status of Mother } \\
\hline Illiterate & 33 & 41 \\
\hline Primary & 48 & 59 \\
\hline \multicolumn{3}{|l|}{ Education Status of Father } \\
\hline Illiterate & 17 & 21 \\
\hline Primary & 56 & 69 \\
\hline High school & 8 & 10 \\
\hline \multicolumn{3}{|c|}{ Perceived economic status (family) } \\
\hline Good & 46 & 57 \\
\hline \multirow[t]{2}{*}{ Bad } & 35 & 43 \\
\hline & $\mathrm{M} \pm \mathrm{SD}$ & Min-Max. \\
\hline Age to start work(years) & $9.8 \pm 1.31$ & $7-13$ \\
\hline Working hours/week & $18.2 \pm 9.7$ & $8-64$ \\
\hline Working experience(year) & $1.7 \pm 1$ & $0.3-4$ \\
\hline
\end{tabular}

\section{Problems According to the Problem Classification Scheme}

Of the 42 health problems of the Problem Classification Scheme of the Omaha System, 27 were diagnosed among the participants. These health problems were diagnosed a total of 570 times. More than two-thirds of the problems were diagnosed as actual, and $88 \%$ of all problems were at the individual level. These health problems were related mostly to the psychosocial domain (38\% [9]) and physiological domain (34\% [8]), followed by the health-related behaviours domain (25\% [6]]) and environmental domain (9.5\% [4]). The most common health problems diagnosed in the present study were as follows in descending order: mental health (13\% [72]), neglect (11\% [63]), income (11\% [61]), oral health (9\% [51]), nutrition (7.5\% [43]), personal care (6.5\% [37]), physical 
activity (7\% [166]), sleep and rest patterns (6\% [35]), and neighbourhood/workplace safety (5\% [26]). The signs-symptoms were used 922 times, and the 13 most common signs-symptoms were low/no income (7\% [64]), cariosity (5\% [45]), lack of necessary supervision/oversight (4.5\% [42]), sadness/hopelessness/lower self-esteem (4\% [40]), taking on a new role (4\% [35), being able to buy only basic necessities (3.5\% [33]), somatic complaints/fatigue (3\% [32]), difficulty in managing stress (3\% [31), anxiety/unidentified fears (3\% [30), unwanted role change (3\% [26]), inappropriately left alone (3\% [25]), lack of physical care (2\% [20]), and insufficient sleep/rest for age/physical development (2\% [19]). (Table 2) 
Table 2

Domains, Health and Sign-Symptoms according to Omaha System Problem Classification List of Child Workers (N: 81)

\begin{tabular}{|c|c|c|c|c|c|c|}
\hline Domains & Problems & Frequency(n) & $\begin{array}{l}\text { Percentage } \\
(\%)\end{array}$ & Sign/Symptoms & (n) & )$^{(\%}$ \\
\hline \multirow[t]{3}{*}{ Physiological } & \multirow[t]{2}{*}{ Oral health } & \multirow[t]{2}{*}{51} & \multirow[t]{2}{*}{8.9} & Cariosity & 45 & 5 \\
\hline & & & & $\begin{array}{l}\text { Other (tartar, sensitivity to cold or hot, injured/swelling/bleeding } \\
\text { gums etc.) }\end{array}$ & 27 & 3 \\
\hline & Pain & 12 & 2.1 & Expressing uncomfortable-pain & 14 & 1.5 \\
\hline \multirow[t]{8}{*}{ Environmental } & \multirow[t]{4}{*}{ Income } & \multirow[t]{4}{*}{61} & \multirow[t]{4}{*}{10.7} & Low/no income & 81 & 9 \\
\hline & & & & Only be able to buy basic necessities & 33 & 3.5 \\
\hline & & & & Inability to buy basic necessities & 18 & 2 \\
\hline & & & & Lack of health insurance & 12 & 1 \\
\hline & \multirow{2}{*}{$\begin{array}{l}\text { Neighborhood/workplace } \\
\text { safety }\end{array}$} & \multirow[t]{2}{*}{26} & \multirow[t]{2}{*}{4.6} & Physical hazards & 14 & 1.5 \\
\hline & & & & $\begin{array}{l}\text { Other (environmental pollution, insufficient/unsafe } \\
\text { play/exercise areas, threats/reports of violence, high crime rate } \\
\text { etc.) }\end{array}$ & 39 & 4 \\
\hline & \multirow[t]{2}{*}{ Residence } & \multirow[t]{2}{*}{15} & \multirow[t]{2}{*}{2.6} & Insufficient heating/cooling system & 11 & 1 \\
\hline & & & & unsafe and/or undersized house & 18 & 2 \\
\hline \multirow[t]{17}{*}{ Psychosocial } & \multirow[t]{5}{*}{ Mental health } & \multirow[t]{5}{*}{72} & \multirow[t]{5}{*}{12.6} & Sadness/hopelessness/lower self-esteem & 40 & 4 \\
\hline & & & & Anxiety/unidentified fears & 30 & 3 \\
\hline & & & & Somatic complaints/fatigue & 32 & 3 \\
\hline & & & & difficulty in managing stress & 31 & 3 \\
\hline & & & & $\begin{array}{l}\text { Difficulty in anger management, suicidal thoughts, thoughts of } \\
\text { harming others, self-injury, difficulty concentrating /attention, } \\
\text { blunted emotions, etc. }\end{array}$ & 28 & 3 \\
\hline & Abuse & 4 & .7 & $\begin{array}{l}\text { Harsh/over-discipline, verbal attack, cowardly/timid behavior, } \\
\text { constant exposure to negative criticism/messages etc. }\end{array}$ & 14 & 1.5 \\
\hline & \multirow[t]{2}{*}{ Role change } & \multirow[t]{2}{*}{45} & \multirow[t]{2}{*}{7.9} & Unwanted role change & 26 & 3 \\
\hline & & & & Taking on a new role & 38 & 4 \\
\hline & \multirow[t]{4}{*}{ Interpersonal relationship } & \multirow[t]{4}{*}{26} & \multirow[t]{4}{*}{4.6} & Few shared activities & 12 & 1 \\
\hline & & & & Difficulty in establishing and maintaining relationships & 5 & .5 \\
\hline & & & & Lack of interpersonal communication skills & 6 & 6 \\
\hline & & & & Inability to solve problems without conflict & 4 & .4 \\
\hline & \multirow[t]{5}{*}{ Neglect } & \multirow[t]{5}{*}{63} & \multirow[t]{5}{*}{11.1} & Lack of emotional care/support & 51 & 5.5 \\
\hline & & & & Lack of physical care & 20 & 2 \\
\hline & & & & Lack of necessary supervision/oversight & 42 & 4.5 \\
\hline & & & & Inappropriately left alone & 25 & 3 \\
\hline & & & & Inadequate/delayed medical care & 10 & 1 \\
\hline Health-related & Nutrition & 43 & 7.5 & Malnutrion & 45 & 5 \\
\hline Behaviors & & & & Lower weight: BMI 5th percentile or below in children & 3 & .3 \\
\hline & & & & Over weight: BMI 95th percentile or more in children & 2 & .2 \\
\hline & Personal care & 37 & 6.5 & Lack of physical care (bathing, hand-washing, hair care etc.) & 12 & 1 \\
\hline & Substance use & & & Difficulty in fulfilling daily routines, behavioral changes & 2 & .2 \\
\hline & Sleep and rest patterns & 35 & 6.1 & Insufficient sleep/rest for age/physical condition & 20 & 2 \\
\hline & & & & Insomnia & 19 & 2 \\
\hline & & & & Having nightmares & 6 & 6 \\
\hline
\end{tabular}

Nursing Interventions for Child Workers According to the Intervention Scheme

Page $7 / 14$ 
Figure 2 summarises the four most common health problems of the children and their recorded categories, targets, and frequency of interventions. We used 43 of the 76 targets in the Omaha System Intervention Scheme. We applied a total of 14,586 interventions based on the targets. The six most frequently used targets were as follows: nursing care (28\% [987]), signs/symptoms-mental/emotional (8\% [271]), behaviour modification (6\% [198]), support system (5\% [190]), personal care (7\% [242]), services consulting (7\% [277]), medical/dental care (6\% [277]), and sleeplessness/restlessness (5\% [168]). The interventions were most frequently applied in the teaching, guidance, and counselling category (49\%), followed by the case management category $(21 \%)$.

FIGURE 2

\section{Relationship Between the Health Problems of the Problem Classification Scheme of the Omaha System and Sociodemographic Characteristics}

Table 3 shows the relationship between the health problems and sociodemographic characteristics of the child workers. There was a significant association between mental health problems $(p<.05)$ and family health status; between individual health status and oral health $(\chi 2(1)=8.924, p<.05)$ as well as role change $(\chi 2(1)=5.389, p<.05)$; between maternal education level and oral health $(\chi 2(1)=7.190, p<.05)$ as well as personal care $\chi 2(1)=5.270, p<.05)$; and between nutrition $\chi 2(1)=6.144, p<.05)$ and paternal education level. However, there was no significant association between health problems and nationality (Turkish/Syrian), education and work status of the parents ( $\mathrm{p} \otimes .05)$, except residence problem $(\mathrm{p}<.05)$. In addition, there was a significant association between family economic conditions and neighbourhood/workplace safety $(p<.05)$. 
Table 3

The relationship between the health problems of the problem classification Scheme of the Omaha System and Sociodemographic characteristics of the ch workers (N:81)

\begin{tabular}{|c|c|c|c|c|c|c|c|c|c|c|c|c|}
\hline \multirow[t]{3}{*}{ Problems/statistics } & \multirow{3}{*}{$\begin{array}{l}\text { Results } \\
\left(\mathrm{n} / \%^{\mathrm{a}}\right)\end{array}$} & \multicolumn{11}{|c|}{ Characteristics } \\
\hline & & \multicolumn{2}{|c|}{ Nationality } & \multicolumn{2}{|c|}{$\begin{array}{l}\text { Individual Health } \\
\text { problem/s }\end{array}$} & \multicolumn{2}{|c|}{$\begin{array}{l}\text { Family's health } \\
\text { problem/s }\end{array}$} & \multicolumn{2}{|c|}{$\begin{array}{l}\text { Education status of } \\
\text { mother }\end{array}$} & \multicolumn{3}{|c|}{ Education status of father } \\
\hline & & Turkey & Syria & Yes & No & Yes & No & Primary & Illiterate & Primary & $\begin{array}{l}\text { High } \\
\text { school }\end{array}$ & Illite \\
\hline \multirow[t]{3}{*}{ Oral health } & Yes & $38 / 81$ & $9 / 19$ & $16 / 34$ & $31 / 66$ & $13 / 28$ & $34 / 72$ & $22 / 47$ & $25 / 53$ & $29 / 62$ & $5 / 11$ & $13 /$ \\
\hline & No & $29 / 85$ & $5 / 15$ & $23 / 68$ & $11 / 32$ & $8 / 23.5$ & $26 / 76.5$ & $26 / 76.5$ & $8 / 23.5$ & $27 / 79$ & $3 / 9$ & $4 / 1$ \\
\hline & & $\begin{array}{l}\chi^{2} \\
=.272 \\
d f: 1\end{array}$ & .602 & $\begin{array}{l}\chi 2= \\
8.924\end{array}$ & $\begin{array}{l}\mathrm{df}: 1 \mathrm{p} \\
=.003\end{array}$ & $\begin{array}{l}\chi 2=. .175 \\
d f: 1\end{array}$ & .675 & $\begin{array}{l}\chi 2= \\
7.190 \\
d f: 1\end{array}$ & $P=.007$ & $\begin{array}{l}\chi 2^{b}=3.297 \\
d f: 2\end{array}$ & $\begin{array}{l}\mathrm{p} \\
=.181\end{array}$ & \\
\hline \multirow[t]{3}{*}{ Nutrition } & Yes & $36 / 86$ & $6 / 14$ & $21 / 50$ & $21 / 50$ & $12 / 29$ & $30 / 71$ & $21 / 50$ & $21 / 50$ & $33 / 79$ & $1 / 2$ & $8 / 1$ \\
\hline & No & $31 / 79.5$ & $8 / 20.5$ & $18 / 46$ & $21 / 54$ & $9 / 23$ & $30 / 77$ & $27 / 69$ & $12 / 31$ & $23 / 59$ & $7 / 18$ & $9 / 2$ \\
\hline & & $\begin{array}{l}\chi^{2} \\
=.548 \\
\mathrm{df}: 1\end{array}$ & .459 & $\begin{array}{l}\chi^{2} \\
=.120\end{array}$ & $\begin{array}{l}\mathrm{df}: 1 \mathrm{p} \\
=.729\end{array}$ & $\begin{array}{l}\chi 2 \\
=.318 \\
d f: 1\end{array}$ & .573 & $\begin{array}{l}\chi 2= \\
3.098 \\
d f: 1\end{array}$ & $P=.07$ & $\begin{array}{l}\chi 2^{b}=6.144 \\
d f: 2\end{array}$ & $\begin{array}{l}\mathrm{P} \\
=.039\end{array}$ & \\
\hline \multirow[t]{3}{*}{ Income } & Yes & $53 / 83$ & $11 / 17$ & $28 / 44$ & $36 / 56$ & $16 / 25$ & $48 / 75$ & $38 / 59$ & $26 / 41$ & $41 / 64$ & $8 / 12.5$ & $15 /$ \\
\hline & No & $14 / 82$ & $3 / 18$ & $11 / 65$ & $6 / 35$ & $5 / 29$ & $12 / 71$ & $10 / 59$ & $7 / 41$ & $15 / 88$ & - & $2 / 1$ \\
\hline & & $b$ & & $\begin{array}{l}\chi 2 \\
=.2 .364\end{array}$ & $\begin{array}{l}\mathrm{df}: 1 \mathrm{p} \\
=.124\end{array}$ & $\begin{array}{l}\chi^{2} \\
=.136 \\
d f: 1\end{array}$ & .712 & $\begin{array}{l}\chi 2=.002 \\
d f: 1\end{array}$ & $P=.967$ & $\begin{array}{l}\chi 2^{b}= \\
3.499 d f: 2\end{array}$ & $\begin{array}{l}\mathrm{P} \\
=.170\end{array}$ & \\
\hline \multirow[t]{3}{*}{ Neglect } & Yes & $53 / 81.5$ & $12 / 12.5$ & $31 / 48$ & $34 / 52$ & $17 / 26$ & $48 / 74$ & $40 / 61.5$ & $25 / 38.5$ & $45 / 69$ & $7 / 11$ & $13 /$ \\
\hline & No & $14 / 87.5$ & $2 / 12.5$ & $8 / 50$ & $8 / 50$ & $4 / 25$ & $12 / 75$ & $8 / 50$ & $8 / 0$ & $11 / 69$ & $1 / 6$ & $4 / 2$ \\
\hline & & $b$ & & $\begin{array}{l}\chi 2 \\
=.027 \\
d f: 1\end{array}$ & $P=.829$ & $\mathrm{~b}$ & .600 & $\begin{array}{l}\chi 2=.708 \\
d f: 1\end{array}$ & $P=.400$ & $\begin{array}{l}\chi 2^{b}=.409 \\
d f: 2\end{array}$ & $\begin{array}{l}\mathrm{P} \\
=.910\end{array}$ & \\
\hline \multirow[t]{3}{*}{ Personal care } & Yes & $26 / 81$ & $6 / 19$ & $14 / 44$ & $18 / 56$ & $11 / 34$ & $21 / 66$ & $14 / 44$ & $18 / 56$ & $21 / 66$ & $2 / 6$ & $9 / 2$ \\
\hline & No & $41 / 84$ & $8 / 16$ & $25 / 51$ & $24 / 49$ & $10 / 20$ & $39 / 80$ & $34 / 69$ & $15 / 31$ & $35 / 71$ & $6 / 12$ & $8 / 1$ \\
\hline & & $\begin{array}{l}\chi 2 \\
=.080 \\
\mathrm{df}: 1\end{array}$ & .778 & $\begin{array}{l}\chi 2 \\
=.410 \\
d f: 1\end{array}$ & $P=.522$ & $\begin{array}{l}\chi 2= \\
1.966 \\
d f: 1\end{array}$ & $P=.161$ & $\begin{array}{l}\chi 2= \\
5.270 \\
d f: 1\end{array}$ & $P=.022$ & $\chi 2^{b}=1.996$ & $\begin{array}{l}\mathrm{p} \\
=.394\end{array}$ & \\
\hline \multirow[t]{3}{*}{ Mental health } & Yes & $55 / 81$ & $13 / 19$ & $35 / 51.5$ & $33 / 48.5$ & $21 / 31$ & $47 / 69$ & $39 / 57$ & $29 / 43$ & $44 / 65$ & $8 / 12$ & $16 /$ \\
\hline & No & $12 / 92$ & $1 / 8$ & $4 / 31$ & $9 / 69$ & - & $13 / 100$ & $9 / 69$ & $4 / 31$ & $12 / 92$ & - & $1 / 8$ \\
\hline & & $.448^{\mathrm{b}}$ & & $\begin{array}{l}\chi 2= \\
7.873 \\
d f: 1\end{array}$ & $P=.171$ & $b$ & $P=.017$ & $\begin{array}{l}\chi 2=.638 \\
d f: 1\end{array}$ & $P=.425$ & $\begin{array}{l}\chi 2^{b}=3.144 \\
d f: 2\end{array}$ & $\begin{array}{l}\mathrm{P} \\
=.200\end{array}$ & \\
\hline \multirow[t]{3}{*}{ Sleep/rest } & Yes & $33 / 85$ & $6 / 15$ & $23 / 59$ & $16 / 41$ & $11 / 28$ & $28 / 72$ & $24 / 61.5$ & $15 / 38.5$ & $26 / 67$ & $3 / 8$ & $10 /$ \\
\hline & No & $34 / 81$ & $8 / 19$ & $16 / 38$ & $26 / 62$ & $10 / 24$ & $32 / 76$ & $24 / 57$ & $18 / 43$ & $30 / 71$ & $5 / 12$ & $7 / 1$ \\
\hline & & $\begin{array}{l}\chi 2= \\
190 \\
d f: 1\end{array}$ & .663 & $\begin{array}{l}\chi 2= \\
3.531 \\
d f: 1\end{array}$ & $P=.06$ & $\begin{array}{l}x 2 \\
=.203 \\
d f: 1\end{array}$ & $P=.652$ & $\stackrel{\chi 2}{=.162 d f: 1}$ & $P=.687$ & $\chi 2^{b}=1.216$ & $\begin{array}{l}\mathrm{p} \\
=.530\end{array}$ & \\
\hline \multirow[t]{3}{*}{ Role change } & Yes & $41 / 82$ & $9 / 19$ & $19 / 38$ & $31 / 62$ & $14 / 28$ & $36 / 72$ & $27 / 54$ & $23 / 46$ & $33 / 66$ & $5 / 10$ & $12 /$ \\
\hline & No & $26 / 84$ & $5 / 16$ & $20 / 64.5$ & $11 / 35.5$ & $7 / 23$ & $24 / 77$ & $21 / 68$ & $10 / 32$ & $23 / 74$ & $3 / 10$ & $5 / 1$ \\
\hline & & $\begin{array}{l}\chi 2 \\
=.047 \\
d f: 1\end{array}$ & .829 & $\begin{array}{l}\chi 2= \\
5.389 \\
d f: 1\end{array}$ & $P=.02$ & $\begin{array}{l}\chi^{2} \\
=.293 \\
d f .1\end{array}$ & $P=.589$ & $\begin{array}{l}\chi 2= \\
7.497 \\
d f: 1\end{array}$ & $\mathrm{P}=.221$ & $\chi 2^{b}=.767$ & $\begin{array}{l}\mathrm{p} \\
=.772\end{array}$ & \\
\hline \multirow[t]{3}{*}{ Residence } & Yes & $9 / 60$ & $6 / 40$ & $10 / 67$ & $5 / 33$ & $3 / 20$ & $12 / 80$ & $10 / 67$ & $5 / 23$ & $11 / 73$ & - & $4 / 2$ \\
\hline & No & $58 / 88$ & $8 / 12$ & $29 / 44$ & $37 / 56$ & $21 / 26$ & $60 / 74$ & $38 / 58$ & $28 / 42$ & $45 / 68$ & $8 / 12$ & $13 /$ \\
\hline & & b & .019 & $\begin{array}{l}\chi 2= \\
2.529 \\
d f: 1\end{array}$ & $P=.112$ & $\mathrm{~b}$ & $P=.748$ & $\begin{array}{l}\chi 2=.418 \\
d f: 1\end{array}$ & $P=.518$ & $\chi 2^{b}=.1 .832$ & $\begin{array}{l}\mathrm{P} \\
=.435\end{array}$ & \\
\hline
\end{tabular}

x2: Pearson Chi-Square a: Within each problem b: Fischer`s Exact test 


\section{Discussion}

The main purpose of this study was to determine the health-related behaviours and the psychosocial, physiological, and environmental health problems of migrant and non-migrant child workers in lower-secondary schools in a suburb of Istanbul via the Omaha Problem Classification Scheme. The study also investigated the suitability of the Omaha System in the evaluation and follow-up of health problems among the children, and to present scientific data regarding any associations between the sociodemographic characteristics of the child workers and health problems.

The Omaha System has been used in a variety of medical fields, such as ageing health (32), school health (33), occupational health (34), and clinical care (28), and in education and research (35) in Turkey and abroad. The results showed that the system was very successful in detecting the health problems of individuals and families, as well as society-based problems. However, this is the first study in which the Omaha System was used to detect and monitor the health problems of migrant and non-migrant children who work but are trying to continue schooling. According to the results of this study, the Omaha System seemed to be suitable for diagnosis and follow-up of the health problems of migrant and non-migrant working children, the implementation of public health nursing interventions, targets, and the re-evaluation of the problems of the children. It provides many benefits, such as holistic evaluation of the health of child workers, follow-up, and data storage. It was found to be a very time-saving program, preventing repetition and effectively expediting follow-up for the health problems of each child. Thus, the use of this electronic-based information system may also facilitate the achievement of desired goals by increasing the work motivation and job satisfaction of specialists such as nurses and physicians working in the field.

The results of this study once again showed that children should be kept away from the work environment. Although work is thought to be effective in the development of children's self-confidence and assertiveness, it seems very difficult to commit to a "healthy work environment" for children in families and communities with low socioeconomic status. It can be traumatic for children, especially in countries like Turkey that have difficulty implementing international conventions and national legal regulations As a matter of fact, this study indicated that children who attend school full- or part-time try to make economic contributions to their families by working, instead of playing or resting. The main reason for this is that all the children have parents who are poor and/or working in precarious, unstable jobs. Parents with precarious work conditions and in poverty are under higher risk of unhealthy life conditions. This result was similar to those of other studies conducted in this area of Turkey, and it seems that there has been no changes regarding the reasons for child labour in Turkey $(23,36,37)$ or abroad $(5,7,38)$.

The present study indicated that the child workers had a significant proportion of the 42 problems identified in the Omaha System (64\%). Two-thirds of these problems were found to be active. This may be interpreted as an alarming rate because the was study was conducted in public health, not in hospital. This rate of active problems, signs, and symptoms was above expectations. The most common problems among the children seemed to be psychosocial, such as mental health, neglect, and abuse. However, it seems that such results are not specific to the present study; they are very common among child workers, according to recent studies $(16,20,22,25,39)$. However, the prevalence of abuse and neglect may be increased in cases of low social economic status and among international or domestic migrants. Although there was no statistical difference between migrant and non-migrant children in neglect or abuse, many in the sample (Kurdish students) of the present study were exposed to political or economic oppression and therefore expatriated to Istanbul, which was similarly reported by Kolaç(23).

The present study showed that although the incidence rates for the problems experienced by immigrant and non-immigrant working children differed, no statistically significant difference was found beyond residence. However, it is important to note that a significant number of families of the non-immigrant children have also migrated to Istanbul due to political or economic reasons, have serious problems in adapting to the metropolitan city, and have precarious living conditions. Perhaps, this compulsory internal migration made Turkish child workers more vulnerable. On the other hand, it was observed that the probability of experiencing personal care and oral health problems, which are among basic health behaviours, was increased with having an illiterate mother. This study also showed that there is a significant relationship between paternal education level and nutrition. These results are in line with those in the study of variety of child and adolescents(14,40-43). These results show once more the importance of the education of parents for the health of their children.

\section{Strengths and Limitations}

The strength of this study is its application of the internationally reliable electronic-based Omaha System in public health nursing care in the fields of occupational and school health. The Omaha System provides a standardised language between experts such as nurses and physicians in the mentioned fields. The program allows experts and researchers to determine the health problems of children in a holistic approach. The present study reported important scientific data regarding migrant and non-migrant child workers' health problems and sociodemographic characteristics. Although the sample consisted of child workers who speak Kurdish and/or Arabic as a mother tongue, they were also fluent in Turkish. Therefore, there was no need for interpreters during the study process. However, the results of the study are limited to the participants. Because this is the first known study to evaluate the health problems of child workers via the Omaha System, the results cannot be compared to others. Other limitations are due to its cross-sectional observational design.

\section{Conclusion}

The present study reported many health problems of child workers via the Omaha System, which is widely used in research, education, and public health. The program was found suitable for determining, planning an intervention for, following up, and re-evaluating the problems of migrant and non-migrant children. The most frequent health problem among the children was income, followed by psychosocial health problems such as mental health issues and neglect. The study also showed that a majority of participants had health problems associated with nutrition, sleep/rest, personal care, and residence, which are related to the basic needs/rights of every child from birth. It is also important to note that the frequency of neglect and abuse among the children requires the attention of authorities. Beyond that, there was no statistically significant difference between the migrant and non-migrant children regarding health problems. However, the important rate of the non-migrant child workers was also so vulnerable, while most were exposed to harsh, precarious life conditions in the suburb of 
Istanbul after migrating from the east of Turkey (where Kurdish people are the majority) due to political oppression and poor economic conditions. In addition, the present study reported that the education of parents is likely to make a positive difference in the health and quality of life of their children. Therefore, social sensitivity and awareness should be raised by keeping on the agenda, with public advertisements, that child labour has multidimensional, negative effects on

the development and health of children, and that health problems experienced especially in childhood become more severe in advanced ages. However, for the basic solution of the problem, it is necessary to prevent poverty, develop the understanding of the social state, and comply with legal norms. For short-term solutions, the development of child- and immigrant-friendly policies and the enforcement of existing laws are urgently needed. We recommend that researchers examine the health of child workers in long-term and mixed-method observational studies.

\section{Declarations}

\section{Ethics approval and consent to participate}

The Ethical Committee of Clinical Research, Marmara University approved the study phase (no:09.2019.388) before the study was conducted. Formal consent was obtained from the provincial directorate of education. Written informed consent was obtained from the children and their families. All methods were performed in accordance with the Declaration of Helsinki.

\section{Consent publication}

Not applicable

\section{Availability of data and material}

The datasets generated and/or analysed during the current study are not publicly available due to data confidentiality but are available from the corresponding author on reasonable request.

\section{Competing interest}

The authors have no competing interest.

\section{Funding}

Not applicable

\section{Author Contributions}

O.K.O. conceptualized the study and developed the method, search strategy, and study design. O.K.O., S.O. and N.K. reviewed the children, evaulated health problems and made a plan for nursing interventions. O.K.O. and N.K. entered the data into a web-based electronic Omaha program (Nightingale Notes Software). O.K.O. analysed and synthesized the data, and drafted the manuscript. All authors contributed to the manuscript and approved its final version.

\section{Acknowledgements}

This study received no specific grant from any funding agency. One of the authors (OKO) received a scholarship within the Alexander-von-Humboldt foundation's Philipp-Schwartz-Initiative. The scholarship provider played no role in the study design, the collection, analysis and interpretation of the data, the writing of the report, or the decision to submit the paper for publication. Special thanks to the children, their families, teachers and the administrators at the schools.

\section{References}

1. International Labour Organization. Child Labour: Global estimates 2020 [Internet]. 2022. Available from: https://www.ilo.org/ipec/ChildlabourstatisticsSIMPOC/WCMS_817698/lang-en/index.htm

2. UNICEF. Child labour [Internet]. 2021. Available from: https://www.unicef.org/protection/child-labour

3. Turkisch Statistical Institute. Statistics on Child, 2020 [Internet]. 2021. Available from: https://data.tuik.gov.tr/Bulten/Index?p=Statistics-on-Child-202037228\&dil=2

4. International Labour Organization. Ending Child Labour by 2025. A review of policies and programmes [Internet]. Geneva; 2018. Available from: https://www.ilo.org/wcmsp5/groups/public/--ed_norm/--ipec/documents/publication/wcms_653987.pdf

5. Enebe NO, Enebe JT, Agunwa CC, Ossai EN, Ezeoke UE, Idoko CA, et al.Prevalence and predictors of child labour among junior public secondary school students in Enugu, Nigeria: a cross-sectional study. BMC Public Health. 2021;21(1):1-12. 
6. Ministery of National Education. National Education Statistics, Formal Education 2019/'20 [Internet]. Ankara; 2019. Available from: http://sgb.meb.gov.tr/meb_iys_dosyalar/2020_09/04144812_meb_istatistikleri_orgun_egitim_2019_2020.pdf

7. Kaur N, Byard RW. Prevalence and potential consequences of child labour in India and the possible impact of COVID-19 - a contemporary overview. Med Sci Law [Internet]. 2021;61(3):208-14. Available from: https://doi.org/10.1177/0025802421993364

8. Pérez-Herrera N, León-Martínez LD de, Flores-Ramírez R, Barbier O, Ortega-Romero M, May-Euán F, et al. Evaluation of benzene exposure and early biomarkers of kidney damage in children exposed to solvents due to precarious work in ticul, yucatán, méxico. Ann Glob Heal. 2019;85(1):1-8.

9. Batomen Kuimi BL, Oppong-Nkrumah O, Kaufman J, Nazif-Munoz JI, Nandi A. Child labour and health: a systematic review. Int J Public Health [Internet]. 2018;63(5):663-72. Available from: https://doi.org/10.1007/s00038-018-1075-9

10. Scott NB, Pocock NS. The health impacts of hazardous chemical exposures among child labourers in low-and middle-income countries. Int $\mathrm{J}$ Environ Res Public Health. 2021;18(10).

11. Sturrock S, Hodes M. Child labour in low- and middle-income countries and its consequences for mental health: a systematic literature review of epidemiologic studies. Eur Child Adolesc Psychiatry. 2016;25(12):1273-86.

12. Meyer SR, Yu G, Rieders E, Stark L. Child labor, sex and mental health outcomes amongst adolescent refugees. J Adolesc [Internet]. 2020;81(April):52-60. Available from: https://doi.org/10.1016/j.adolescence.2020.04.002

13. Ornek OK, Esin MN. Psychological Health Problems Among Adolescent Workers and Associated Factors in Istanbul, Turkey. Saf Health Work [Internet]. 2018;9(1):101-8. Available from: http://dx.doi.org/10.1016/j.shaw.2017.06.004

14. Ornek OK. Psychological Symptoms Among Child Workers: A Systematic Review. J Contin Med Educ (Sted) Publ Turk Med Assoc. 2017;26(4):151-61.

15. Pandey R, Gupta S, Upadhyay A, Gupta RP, Shukla M, Mishra RC, et al. Childhood maltreatment and its mental health consequences among Indian adolescents with a history of child work. Aust N Z J Psychiatry. 2020;54(5):496-508.

16. Dhakal S, Niraula S, Sharma NP, Sthapit S, Bennett E, Vaswani A, et al. History of abuse and neglect and their associations with mental health in rescued child labourers in Nepal. Aust N Z J Psychiatry [Internet]. 2019;53(12):1199-207. Available from: https://doi.org/10.1177/0004867419853882

17. Wickham S, Whitehead M, Taylor-Robinson D, Barr B. The effect of a transition into poverty on child and maternal mental health: a longitudinal analysis of the UK Millennium Cohort Study. Lancet Public Heal [Internet]. 2017;2(3):e141-8. Available from: http://dx.doi.org/10.1016/S2468-2667(17)30011-7

18. UNICEF. The state of world's children 2021. On My Mind. Promoting, protecting and caring for children's mental health [Internet]. 2021. Available from: https://reliefweb.int/sites/reliefweb.int/files/resources/SOWC-2021-full-report-English.pdf

19. Ornek OK, Sevim E. Work-Related Stress and Coping Profiles among Workers in Outer Garment Sector. COJ Nurs Healthc. 2018;3:1-7.

20. Habib RR, Mikati D, Al-Barathie J, Younes EA, Jawad M, Asmar K El, et al. Work-related injuries among Syrian refugee child workers in the Bekaa Valley of Lebanon: A gender-sensitive analysis. PLoS One [Internet]. 2021;16(9 September):1-17. Available from: http://dx.doi.org/10.1371/journal.pone.0257330

21. Health and Safety Labour Watch. 2020 yılında en az 2427 işçi iş cinayetlerinde hayatını kaybetti... - 2020 Yılı İş Cinayetleri Raporu (At least 2427 workers lost their lives in occupational homicides in 2020... - Work Homicide Report for 2020) [Internet]. 2021. Available from: http://isigmeclisi.org/20607-2020yilinda-en-az-2427-isci-is-cinayetlerinde-hayatini-kaybetti

22. Schlick C, Joachin M, Briceño L, Moraga D, Radon K. Occupational injuries among children and adolescents in Cusco Province: A cross-sectional study. BMC Public Health. 2014;14(1):1-8.

23. Nurcan Kolaç, Ayşe Ergün, Saime Erol. Pazarda Çalışan Çocukların Çalışma Koşullari ve Sağlık Durumları (Working Conditions and Health Conditions of Children Working in the Market). Mesleki Sağlık ve Güvenlik Derg [Internet]. 2006;7(26):30-6. Available from:

http://www.ttb.org.tr/dergi/index.php/msg/article/view/396/374

24. Punch S. Migration Projects: Children on the Move for Work and Education. Workshop on Independent Child Migrants: Policy Debates and Dilemmas [Internet]. Workshop on Independent Child Migrants: Policy Debates and Dilemmas 2007 p. 1-19. Available from:

http://www.sussex.ac.uk/Units/SCMR/drc/news/reports/icm/Punch_migration_paper.pdf

25. Khatab K, Raheem MA, Sartorius B, Ismail M. Prevalence and risk factors for child labour and violence against children in Egypt using Bayesian geospatial modelling with multiple imputation. PLoS One. 2019;14(5):1-20.

26. Lordoglu K, Aslan M. Görünmeyen Göçmen Çocukların İşçiliği: Türkiye'deki Suriyeli Çocuklar (Labor of Invisible Migrant Children: Syrian Children in Turkey ). Çalışma ve Toplum. 2018;2:715-32.

27. Martin KS. The Omaha System: A key to practice, documentation, and information management. Elsevier Saunders; 2005.

28. Ornek OK, Ardic A. Evaluation of Nursing Practice in Patients With HIV/AIDS with the Omaha System Electronic-Based Information Program: A Retrospective Study. CIN Comput Informatics, Nurs. 2019;37(9):482-90.

29. Monsen KA, Schenk E, Schleyer R, Schiavenato M. Applicability of the Omaha System in Acute Care Nursing for Information Interoperability in the Era of Accountable Care. Am J Accountable Care. 2015;3(3):53-61.

30. Erdogan S, Esin NM. The Turkish version of the Omaha System: Its use in practice-based family nursing education. Nurse Educ Today. 2006;26(5):396402.

31. Lee S, Kim E, Monsen KA. Public health nurse perceptions of Omaha System data visualization. Int J Med Inform [Internet]. 2015;84(10):826-34. Available from: http://dx.doi.org/10.1016/j.ijmedinf.2015.06.010

32. ilgaz A, gözüm S. Integrative Nursing and Omaha System-Based Nursing Care Interventions in Older Women Feeling Loneliness (INOSEL): Study Protocol for a Randomized Controlled Trial. J Holist Nurs. 2021;39(3):225-38.

33. Ilgaz A. Effect of health screening and School Nurse Interventions on primary school students' knowledge, behavior, and status in Turkey: A quasiexperimental Omaha System study. J Pediatr Nurs. 2022;62:e115-24.

Page $12 / 14$ 
34. Kesgin MT, Kublay G. Using the Omaha System in Occupational Health Nursing Applications: Advantages of a Common Language in the Diagnosis, Intervention and Evaluation of Nurses' Health Problems. Procedia - Soc Behav Sci [Internet]. 2014;152(Birol 2004):488-94. Available from: http://dx.doi.org/10.1016/j.sbspro.2014.09.238

35. Erdogan S, Secginli S, Cosansu G, Nahcivan NO, Esin MN, Aktas E, et al. Using the omaha system to describe health problems, interventions, and outcomes in home care in Istanbul, Turkey: A student informatics research experience. CIN - Comput Informatics Nurs. 2013;31(6):290-8.

36. Karadeniz O, Akın E, Abacı Ni. Fındık tarımında çocuk işçiliği: Giresun ili Piraziz ilçesi örneği (Child labor in hazelnut farming: The example of Piraziz district of Giresun province). Anadolu J Agric Sci. 2021;36:398-407.

37. Ozmen K, Dönmez İ. Sokakta Çalışan/Çalıştırılan Çocuklar Üzerine Bïr Alan Araştırması (A Field Study on Children Working/Working on the Street). Bingöl Üniversitesi Sos Bilim Enstitüsü Derg. 2021;11(22):753-72.

38. Kim J, Rana S, Lee W, Haque SE, Yoon JH. How the Bidi Tobacco Industry Harms Child-workers: Results From a Walk-through and Quantitative Survey. Saf Health Work [Internet]. 2020;11(2):143-51. Available from: https://doi.org/10.1016/j.shaw.2020.02.002

39. Jalili Moayad S, Mohaqeqi Kamal SH, Sajjadi H, Vameghi M, Ghaedamini Harouni G, Makki Alamdari S. Child labor in Tehran, Iran: Abuses experienced in work environments. Child Abus Negl [Internet]. 2021;117(March):105054. Available from: https://doi.org/10.1016/j.chiabu.2021.105054

40. Köseoğlu Örnek Ö, Kürklü A. Healthy Lifestyle Behaviours, Levels of Self Efficacy Among University Students and Affected Factors. Turkiye Klin J Nurs. 2017;9(3):207-17.

41. Fu E, Grimm KJ, Berkel C, Smith JD.Parenting and social-ecological correlates with children's health behaviours: A latent profile analysis. Pediatr Obes. 2020;15(10):1-11.

42. Elinder LS, Heinemans N, Zeebari Z, Patterson E. Longitudinal changes in health behaviours and body weight among Swedish school children associations with age, gender and parental education - the SCIP school cohort. BMC Public Health. 2014;14(640):1-9.

43. Nurelhuda NM, Trovik TA, Ali RW, Ahmed MF. Oral health status of 12-year-old school children in Khartoum state, the Sudan; a school-based survey. BMC Oral Health. 2009;9(15):1-9.

\section{Figures}

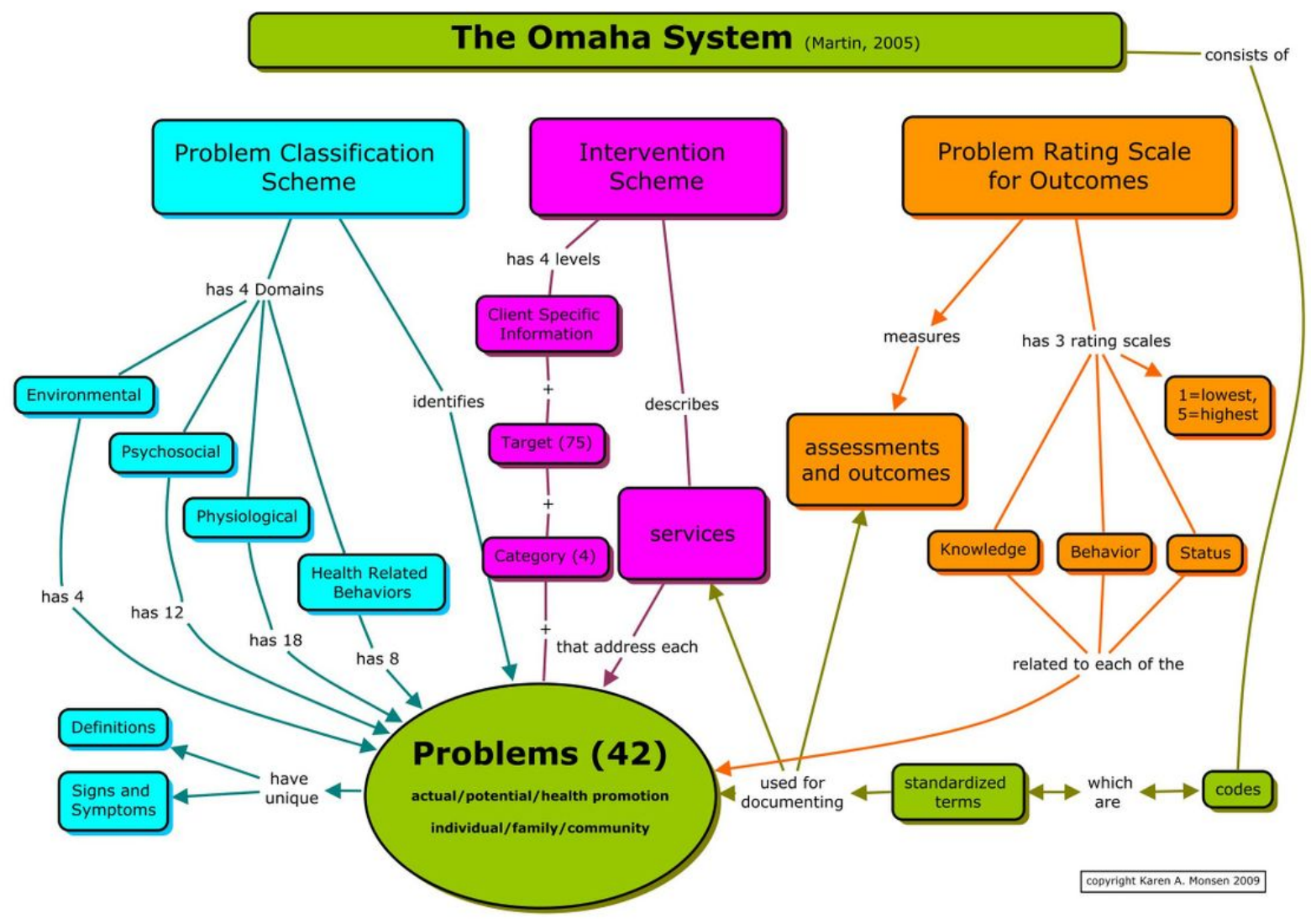

Figure 1 


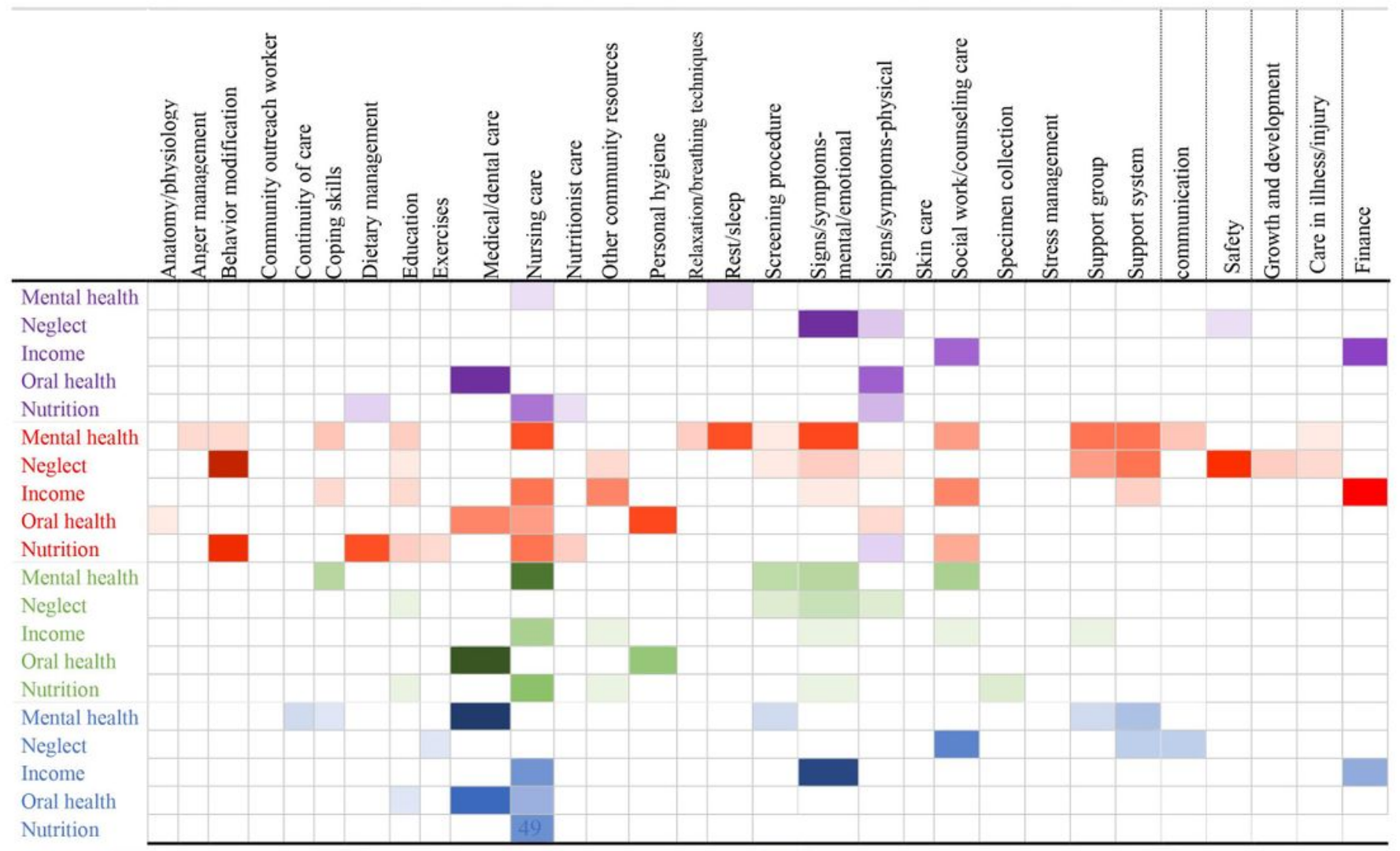

(S) =Surveillance $\quad$ =Teaching, Guidance and Counseling (TGC) $\quad=$ Treatments and Procedures (TP)

$=$ Case Management $(\mathrm{CM})$

Figure 2 shows the matrix visualization for problems and interventions for one patient having five problems. The problems are shown on the $\mathrm{Y}$ axis, including all categories represented by color, Targets shown on the $\mathrm{X}$ axis. Shading indicates number of interventions (darker $=$ more)

Figure 2

The matrix visualization 